\title{
Targeting Phosphoinositide 3-Kinase - Five Decades of Chemical Space Exploration
}

\author{
Chiara Borsari and Matthias P. Wymann*
}

\begin{abstract}
Phosphoinositide 3-kinase (PI3K) plays a key role in a plethora of physiologic processes and controls cell growth, metabolism, immunity, cardiovascular and neurological function, and more. The discovery of wortmannin as the first potent PI3K inhibitor (PI3Ki) in the 1990s provided rapid identification of PI3K-dependent processes, which drove the discovery of the PI3K/protein kinase B (PKB/Akt)/target of rapamycin (mTOR) pathway. Genetic mouse models and first PI3K isoform-specific inhibitors pinpointed putative therapeutic applications. The recognition of $\mathrm{PI} 3 \mathrm{~K}$ as target for cancer therapy drove subsequently drug development. Here we provide a brief journey through the emerging roles of PI3K to the development of preclinical and clinical PI3Ki candidates.
\end{abstract}

Keywords: Drug discovery $\cdot$ Kinase inhibitors $\cdot$ mTOR $\cdot$ PI3K $\cdot$ Phosphoinositide $\cdot$ Wortmannin

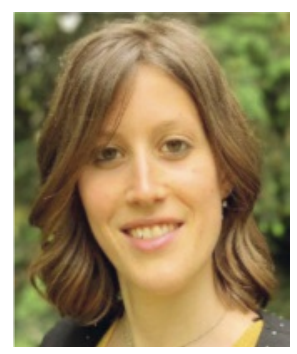

Chiara Borsari is a senior postdoctoral fellow and co-lecturer at the University of Basel. Her research is focused on the development of kinase inhibitors, with a particular attention on PI3K and mTOR signalling pathway. After the successful discovery and optimization of reversible lead compounds, she is currently leading a variety of projects on covalent inhibitors, PROTACs and bifunctional compounds. After research visits at the NHRF in Athens and the State University of New York at Albany, USA, she obtained her $\mathrm{PhD}$ from the University of Modena and Reggio Emilia (Italy) in 2017. She is a board member of the EFMC-YSN (European Federation of Medicinal Chemistry and Chemical Biology - Young Scientists Network) and the EFMC Communication Team.

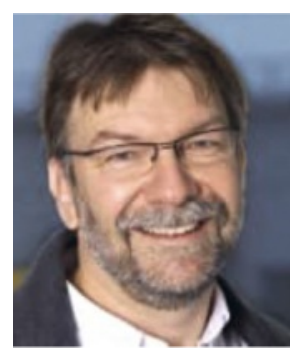

Matthias P. Wymann is professor at the Department of Biomedicine at the University of Basel. He graduated from the Theodor Kocher Institute in Berne in 1988, performed post-doctoral studies at the Institute of Microbiology in Linköping, Sweden, and started independent research at the University of Fribourg in 1991; in 2004 he took up his current position. He discovered the first PI3K inhibitor, wortmannin, and elucidated its covalent PI3K interactions. In various EU framework programs (ACID, MAIN) and the ESF program Euromembranes (TraPPs) he investigated PI3K $\gamma$ function in chronic inflammation and metabolism and produced chemical (PI3K) probes that fueled clinical development programs.

\section{Phosphoinositide Signaling - History}

The correlation between phosphoinositide levels and cell surface receptor signaling was first suggested by experiments of
Lowell and Mabel Hokin in the 1950s, who observed that acetylcholine increased the incorporation of radioactive inorganic phosphate into lipids. ${ }^{[1]}$ Twenty years later, Michell and Lapetina connected the receptor-stimulated phosphoinositide turnover with the increase of inositol phosphate, diacylglycerol (DAG) and cytosolic calcium levels. ${ }^{[2,3]}$ Streb, Irvine, Berridge and Schulz finally resolved the receptor-initiated activation of phospholipase $\mathrm{C}$ and the hydrolysis of phosphatidylinositol(4,5)-bisphosphate $\left(\mathrm{PI} P_{2}\right)$ to DAG and inositol $(1,4,5)$-trisphosphate $\left(\mathrm{I} P_{3}\right)$, which triggered a cytosolic calcium $\left[\mathrm{Ca}^{2+}{ }_{i}\right]$ increase. ${ }^{[4,5]} \mathrm{DAG}$ and $\mathrm{Ca}^{2+}{ }_{i}$ were then found to translocate and activate the Ser/Thr protein kinase C (PKC) discovered in Nishizuka's lab, ${ }^{[6-8]}$ the first known effector kinase dependent on phosphoinositide turnover.

A new chapter of phosphoinositide signaling was opened when several groups independently discovered a lipid kinase activity that was associated with transforming viruses and could phosphorylate phosphatidylinositol. Balduzzi's lab detected the lipid kinase in avian sarcoma virus, ${ }^{[9]}$ Erickson and Cantley found it associated with v-Src from Rous sarcoma virus, ${ }^{[10]}$ and Kaplan, Cantley and Roberts identified a p85 kD protein that was co-immunoprecipitated from cells transformed with polyoma middle $\mathrm{T}$ antigen. ${ }^{[11]}$ With the contribution of the Downes lab, the lipid product was identified as phosphatidylinositol(3)-phosphate (PI-3P), assigning this novel lipid kinase the ability to phosphorylate the 3 '-OH position of the inositol headgroup. ${ }^{[12]}$

As it turned out later, however, PI-3P was not the primary signal produced downstream of the cell surface receptor-activated lipid kinase: Traynor-Kaplan and Sklar isolated from neutrophils stimulated with the $G$ protein-coupled receptor (GPCR) ligand fMLP (formyl-Met-Leu-Phe peptide) an inositol tetrakisphosphate $\left(\mathrm{IP}_{4}\right)$ containing lipid, and identified the latter as phosphatidylinositol $(3,4,5)$-trisphosphate $\left(\mathrm{PI} P_{3}\right.$, Fig. 1a). ${ }^{[16,17]}$

Using rapid metabolic labelling with ${ }^{32} P_{\mathrm{i}}$, Hawkins and Stephens demonstrated subsequently that upon stimulation of the platelet-derived growth factor (PDGFR) the last phosphate group transferred from ATP to the inositol headgroup is added to the $3^{\prime}-\mathrm{OH}$ position to form $\mathrm{PI} P_{3}$ (Fig. $1 \mathrm{a}$ and b). ${ }^{[18]}$ These experi- 

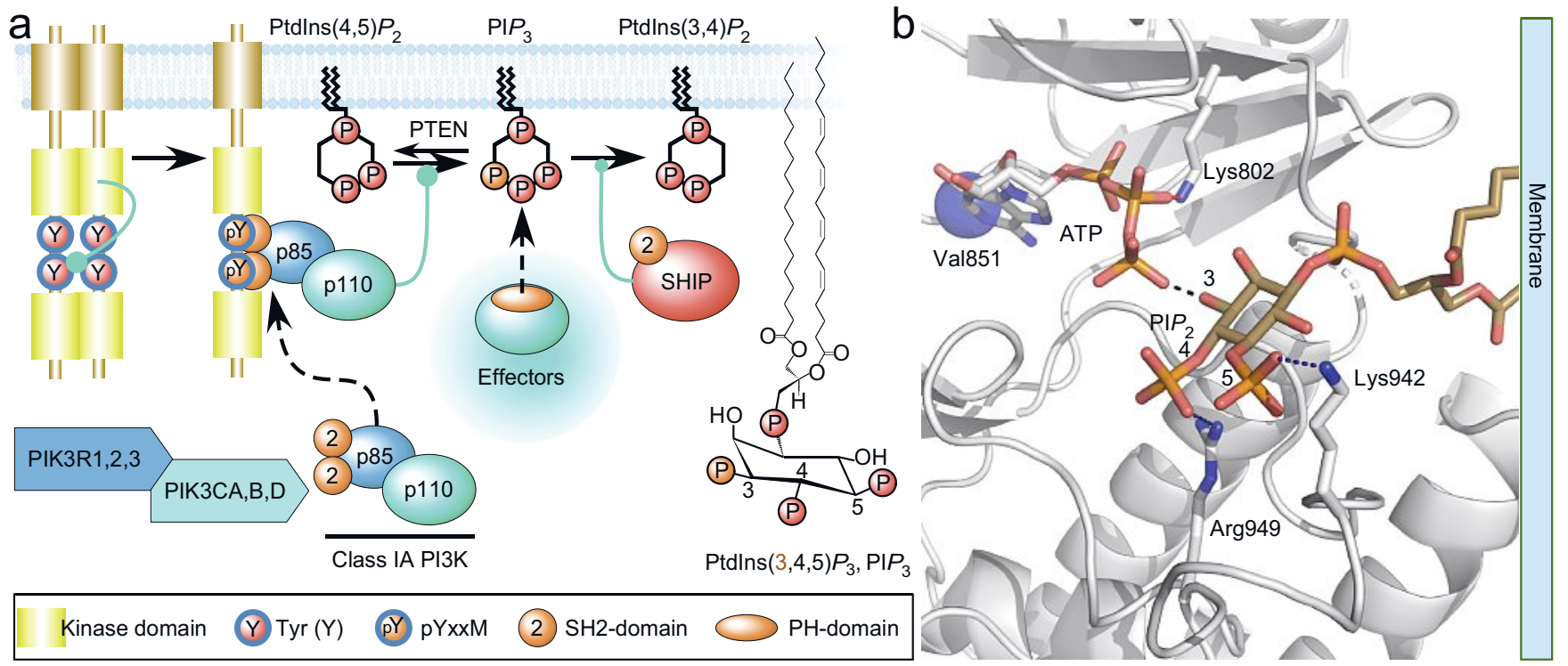

Fig. 1. a) Activation of class IA PI3Ks by growth factor receptors (GFR): regulatory subunits (p85-like proteins, encoded by the three PIK3R1-3 loci) contain two src-homology 2 domains that bind to phosphorylated YxxM (Tyr-x-x-Met) motifs on GFR chains after receptor dimerization and translocate the catalytic p110 kD Class IA PI3K subunits (encoded by PIK3CA, B, D genes) to the membrane. Translocated PI3K gets access to plasma membrane-bound $\mathrm{PI} P_{2}$ to produce Ptdlns $(3,4,5) P_{3}\left(\mathrm{PI} P_{3}\right)$. Effector proteins such as protein kinase $\mathrm{B}$ (PKB/Akt) or phosphoinositide-dependent kinase 1 (PDK1) containing a pleckstrin homology (PH) domain recognize $\mathrm{PIP}_{3}$ and initiate downstream signaling cascades. PTEN (a 3-phosphatase) and SHIP (a 5-phosphatase) counteract PI3K activity. b) 3D model of the transfer of the ATP $\gamma$-phosphate group to the 3-OH position of PIP ${ }_{2}$ Lys802 in $\mathrm{p} 110 \alpha$ (Lys833 in $\mathrm{p} 110 \gamma$ ) activates ATP by interaction with the $\beta$-phosphate group of ATP, while positive charges in the so-called activation loop (Lys942, Arg949) compensate for the negatively charged poly-phosphoinositol headgroup. If mutated, class I PI3Ks become incapable to process $\mathrm{PIP}_{2}{ }^{\left[{ }^{13,14]}\right.}$ For an extended historical perspective on phosphoinositide signaling consult ref. [15].

ments showed elegantly that the enzyme activity downstream of the PDGFR and the fMLP receptor was what we call today a class I phosphoinositide 3-kinase (PI3K), forming PI $P_{3}$ from ATP and PI $P_{2}$. Carpenter and Cantley purified this PI3K ${ }^{[19]}$ and kindly distributed it to other labs, including ours, to produce radioactive poly-phosphoinositide standards. The first cloning of the catalytic PI3K $\alpha$ subunit, p110 $\alpha$, was then achieved in Waterfield's lab.[20] Not much later Emr and colleagues showed that Vps34, required for vacuolar protein sorting in S. cerevisiae, was a phosphatidylinositol 3-kinase (PtdIns 3-K). Kunz and Hall cloned from the same organism the target of rapamycin (TOR) with homology to p110 $\alpha$ and Vps34.[21] It was initially not excluded that rapamycin blocked TOR's lipid kinase activity, before the mammalian orthologue, initially dubbed FKBP-rapamycin-associated protein (FRAP), ${ }^{[22]}$ was shown to phosphorylate and activate S6 kinase (S6K) - which already laid out a rudimentary signaling pathway from growth factor receptors to cell growth at that time.

The oncogenic potential of PI3K was then later confirmed by three seminal findings: the frequently mutated tumor suppressor Phosphatase and Tensin homolog (PTEN/MMAC1), initially identified as a protein tyrosine phosphatase, ${ }^{[23]}$ was showed to hydrolyze PI $P_{3}$ to generate PI $P_{2}$ by Maehama and Dixon ${ }^{[24]}$ and others, ${ }^{[25,26]}$ thus reversing the action of PI3K. Finally it was demonstrated that PIK3CA encoding p $110 \alpha$ was frequently mutated in human tumors by Samuels and Velculescu, ${ }^{[27,28]}$ and Brugge's and Vogt's groups ${ }^{[29,30]}$ could then demonstrate that the expression of mutated $\mathrm{p} 110 \alpha$ could transform mammalian cells. In spite of these findings identifying PI3K as a target in oncology, early reports of embryonic lethality in mice with a genetically targeted PIK3CA ${ }^{[31]}$ or PIK3CB (encoding p110 $\left.\beta\right)^{[32]}$ locus dampened initially the enthusiasm to develop drug targeting programs for PI3K.

\section{Nature - First Source of PI3K Inhibitors}

Unnoticed by the scientific community, nature selected PI3Ks early on as a target and devised natural compounds for biological warfare. In 1957 Brian et al. ${ }^{[33]}$ isolated from a broth of Penicillium wortmannii a compound with specific antifungal activities, which was named wortmannin. Only in 1972 was the absolute structure of wortmannin determined (Fig. 2a). ${ }^{[39]}$ In the following years, wortmannin and 2,3-dihydrobenzofuran-2-one derivatives inspired by wortmannin were shown to have anti-inflammatory properties in rat models of carrageenan-induced paw edema and adjuvantinduced arthritis. ${ }^{[40]}$ However, these compounds also showed considerable toxicity and immune suppression. ${ }^{[41]}$ Baggiolini and collaborators reported later that wortmannin inhibited the so-called respiratory burst in neutrophils, ${ }^{[42]}$ now known as the production of superoxide anions $\left(\mathrm{O}_{2}^{-}\right)$by NADPH-oxidase. When respiratory burst measurements were refined by the use of chemiluminescent assays, ${ }^{[43]}$ oscillatory dynamics of $\mathrm{O}_{2}^{-}$production became apparent in wortmannin treated neutrophils. Those correlated with coordinated cycles of actin polymerization and shape changes, ${ }^{\text {[44-46] }}$ but did not go along with fluctuations in second messengers at the time. A report that claimed phospholipase C (PLC) and D (PLD) were direct targets of wortmannin in neutrophils ${ }^{[34]}$ did not provide signals explaining these oscillations. When we investigated poly-phosphoinositide pools in fMLP-stimulated neutrophils metabolically labelled with ${ }^{32} \mathrm{P}_{i}$, we found that wortmannin at nM concentrations blocked agonist-induced elevations of cellular PI $P_{3}$ and also inhibited PI3K reactivity immunoprecipitated with anti-p85 antibodies. ${ }^{[47]}$ In fibroblasts stimulated with PDGF, wortmannin abolished actin rearrangements and PI $P_{3}$ elevations at the same time, but did not interfere with the PDGFR-mediated Tyr phosphorylation of the $\mathrm{p} 85$ regulatory subunit. ${ }^{[48]}$ Similarly, Yano and Matsuda documented the inhibition of IgE-mediated histamine secretion by wortmannin in TBL-2H3 cells, and also found that wortmannin-derivatives with an open and substituted furane ring lost the capacity to inhibit PI3K. ${ }^{[38]}$ This, together with the fact that tritiated wortmannin was retrieved with a $110 \mathrm{kD}$ protein on denaturing gel electrophoresis, ${ }^{[49]}$ suggested that wortmannin was a covalent inhibitor of PI3K. We identified the covalent bind- 


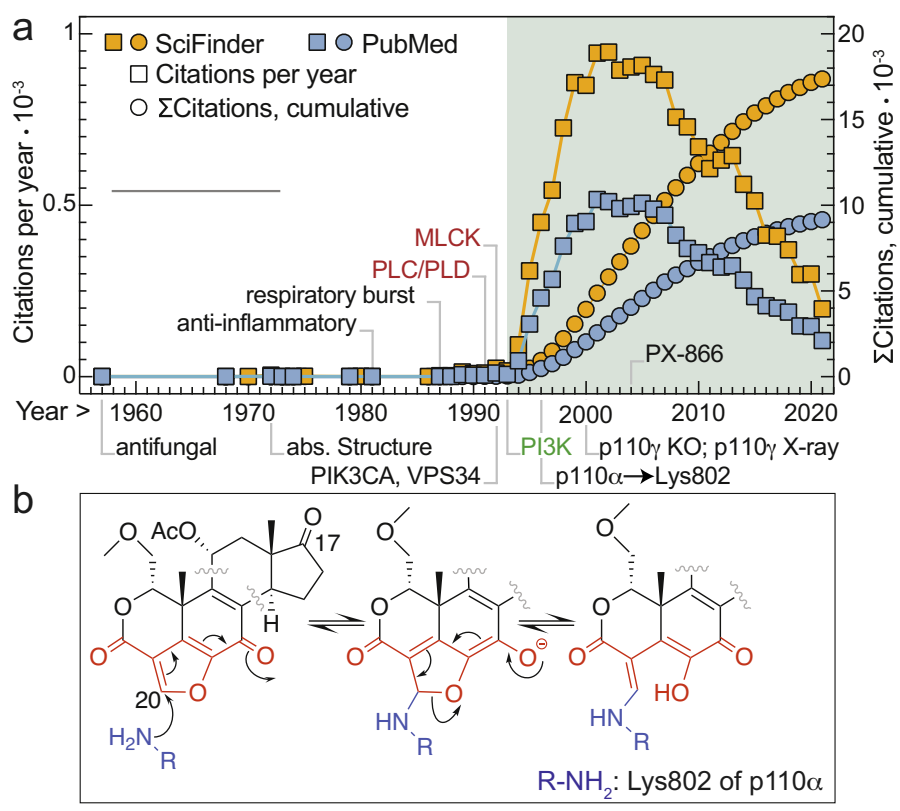

Fig. 2. a) Publications on wortmannin in PubMed and Scifinder over time. The interest for the compound increased significantly after the identification of phosphoinositide 3-kinase (PI3K) as a nM target. Phospholipase C (PLC) and PLD reported earlier to be inhibited by wortmannin $^{[34]}$ were affected indirectly. Myosin light chain kinase ${ }^{[35]}$ is inhibited at elevated wortmannin concentrations. b) Mechanism of the nucleophilic attack of Lys802 of p110 $\alpha$ at the furan C20 of wortmannin and the formation of a covalent link via a Schiff-base. ${ }^{[36]}$ In PI3K $\gamma$, Lys833 is the target residue. The mechanism of Schiff-base formation fits the one proposed in 1975, established for selective functionalization of wortmannin by substitutions masking the furan ring of wortmannin, ${ }^{[37]}$ which render wortmannin-derivatives with an opened furan ring inactive. ${ }^{[38]}$

ing site of wortmannin by proteolytic digestion of wortmanninlabelled PI3K $\alpha(\mathrm{p} 85 \alpha / \mathrm{p} 110 \alpha$-wortmannin complex) and used anti-wortmannin antibodies to detect wortmannin-labeled peptide fragments on immunoblots. The validation of nucleophilic target residues by mutational analysis revealed finally that Lys 802 in $\mathrm{p} 110 \alpha$ attacked wortmannin, ${ }^{[36]}$ while Lys833 did the same in

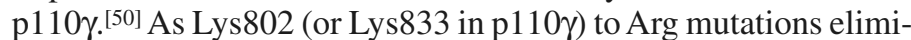
nated all PI3K activity, these results showed that these lysines engaged the $\beta$-phosphate group of ATP to facilitate the $\gamma$-phosphate transfer to $\mathrm{PI} P_{2}$. With wortmannin reversibly bound, the attacking Lys acts as a strong nucleophile that attacks the C20 of wortmannin's furan ring (Fig. 2b) to form a Schiff-base, which is relatively stable at physiologic $\mathrm{pH}$, by a mechanism proposed on the basis of the amine substitutions masking the furane ring carried out by Haefliger and Hauser at Sandoz in 1975. [37]

The link between C20 of wortmannin and Lys833 was confirmed by a high-resolution X-ray crystal structure of PI3K $\gamma$ established in Williams' lab (Fig. 3a). ${ }^{[51]}$ This structure was seminal to spur the development of novel inhibitors. Efforts have been undertaken to stabilize wortmannin, as the compound is rather unstable under physiological conditions. Pegylation yielded PWT-478 ${ }^{[52]}$ and masking the furan ring of wortmannin lead to Sonolisib/PX-866, ${ }^{[53]}$ which reached phase II clinical trials in oncology.

\section{Assembly of the PI3K Pathway}

In parallel, wortmannin and LY294002 (a $\mu \mathrm{M}$ inhibitor of PI3K ${ }^{[54]}$ ) contributed to the assembly of the PI3K signaling pathway. Activation of protein kinase $B$ (also dubbed Akt ${ }^{[55]}$ and related to A and $\mathrm{C}$ kinase [RAC] ${ }^{[56]}$ ) was shown to be wortmanninsensitive, and is translocated to $\mathrm{PI} P_{3}$ via its pleckstrin homology (PH) domain. ${ }^{[57]}$ At the membrane, $\mathrm{PKB} / \mathrm{Akt}$ is phosphorylated on Thr308 by phosphoinositide dependent kinase 1 (PDK1) - which also presents a $\mathrm{PH}$ domain for recruitment to $\mathrm{PI} P_{3}{ }^{[58]}$ Target of rapamycin initially cloned from yeast ${ }^{[21]}$ and identified as FKBP12rapamycin-associated protein (FRAP/RAFT, now called mechanistic target of rapamycin, mTOR) ${ }^{[22]}$ was integrated into the PI3K pathway based on the observation that wortmannin abrogated the phosphorylation of the mTOR substrate S6 kinase (S6K). ${ }^{[64]}$ Although mTOR was thus correctly situated downstream of PI3K, it was later predicted ${ }^{[36]}$ and finally demonstrated that wortmannin and LY294002 inhibited mTOR kinase directly. ${ }^{[65]}$ Further investigations showed that the Raptor (Regulatory-associated protein of mTOR) containing mTOR complex 1 (TORC1) phosphorylated S6K, and TORC2 containing Rictor (Rapamycin-insensitive companion of mTOR) phosphorylated PKB/Akt on Ser473, which unleashed together with the PDK1-mediated Thr308 phosphorylation the full activity of PKB/Akt.[66,67]

The identification of SIN1/MIP1 (Mammalian stress-activated protein kinase interacting protein 1) as a component of TORC2 ${ }^{[68,69]}$ with a $\mathrm{PH}$ domain specific for $\mathrm{PI} P_{3}$ explained then how PKB/Akt, PDK1 and TORC2 are colocalized on PI $P_{3}$ dock-

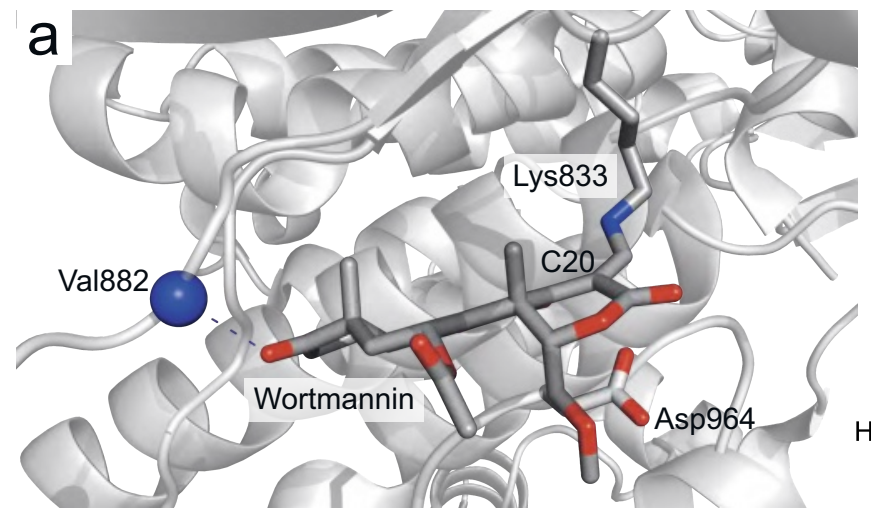<smiles>O=C1NC(=O)C(=Cc2ccc3c(c2)OC(F)(F)O3)S1</smiles><smiles>CC(=O)c1ccc(-c2sc(NC(=O)NCCC(=O)NC(C)(C)C)nc2C)cc1</smiles>

IPI-549<smiles>C[C@H](NC(=O)c1c(N)nn2cccnc12)c1cc2cccc(C#Cc3cnn(C)c3)c2c(=O)n1-c1ccccc1</smiles><smiles>[R20]C(C)=O</smiles>

Fig. 3. a) Wortmannin-p110 $\gamma$ complex joined via C20 and Lys833. ${ }^{[51]}$ Asp964 is the start of the classical DFG motif present in the ATP-binding site of many kinases, and the nitrogen of the hinge Val882 is an important interaction site for many PI3K inhibitors (PI3Ki). b) A selection of PI3K $\gamma$ inhibitors with increasing drug-likeness properties: AS-604850, AS-605240 and AS-242525 are potent PI3K $\gamma$ inhibitors used in many inflammatory mouse models, ${ }^{[59]}$ NVS-PI3-4 has been successfully explored in the attenuation of mast cell activation and allergy in vivo; ${ }^{[60,61]}$ IPI-549/Eganelisib ${ }^{[62]}$ has entered phase II clinical trials as an immuno-oncology candidate; and AZ2 is a highly specific PI3K $\gamma$ with a novel binding mode inducing conformational changes in $\mathrm{PI} 3 \mathrm{~K} \gamma^{\left[{ }^{[33]}\right.}$ 
ing sites to generate a full scale PKB/Akt signal. The PI3K-PKB/ Akt-mTOR pathway has now evolved into a complex network controlling cell growth, proliferation, metastasis, metabolism, immune responses and more, and has been identified as a target in oncology. ${ }^{[70,71]}$

\section{Genetic Models and Pharmacology: First Applications}

In the early days, inhibition of all class I PI3Ks was met with skepticism, which prioritized strategies to produce PI3K isoformspecific inhibitors. As mentioned above, initial genetic inactivation of PI3K $\alpha$ and PI3K $\beta$ yielded embryonic lethality, and the PI3K $\gamma(\mathrm{p} 110 \gamma)$ null mice produced in collaboration with Hirsch's lab (competing with Li's $^{[72]}$ and Penninger's labs ${ }^{[73]}$ ) were the first viable knock-out mice. Loss of p110 $\gamma$ completely abrogated GPCR ligand-induced PI $P_{3}$ production in all tested hematopoietic cells, including neutrophils, macrophages, and dendritic cells, ${ }^{[74-77]}$ which resulted in attenuated chemotaxis towards chemokines in vitro and in vivo. ${ }^{[78-80]}$ In mouse models of rheumatoid arthritis, ${ }^{[59]}$ pancreatitis, ${ }^{[81]}$ and atherosclerosis, ${ }^{[82,83]}$ the first PI3K $\gamma$-specific inhibitors produced at Ares-Serono by Rommel and collaborators (Fig. 3b, AS-604850, AS-605240 ${ }^{[59]}$ ) showed a protective action. Similarly, monocyte and T-cell extravasation were reduced in atherosclerosis, ${ }^{[84]}$ and LDL uptake was attenuated in the absence of PI $3 \mathrm{~K} \gamma$, which slowed the progression of macrophages to foam cells. ${ }^{[85,86]}$

To better fit a pharmacological inhibition of PI3K $\gamma$, mice expressing an inactive PI3K $\gamma$ catalytic subunit (p110 $\gamma^{\mathrm{KD} / \mathrm{KD}}$, a kinasedead Lys833 to Arg mutant) were produced, and a comparison of p110 $\gamma$ null and $\mathrm{p} 110 \gamma^{\mathrm{KD} / \mathrm{KD}}$ mice uncovered a scaffolding function of the p110 $\gamma$ protein: without P110 $\gamma$, cAMP levels in cardiomyocytes and cardiac contraction were elevated due to the loss of phosphodiesterase 3B (PDE3B) activity. ${ }^{[87]}$

That PI3K $\gamma$ is a crucial mediator of metabolic syndrome became clear in Solinas' lab with PI3K $\gamma$ null mice on a high fat diet: in comparison to their wild type counterparts they stayed lean due to increased thermogenesis. ${ }^{[88,89]}$ There is still a lot to learn concerning the implicated cellular networks and if the results in mice can be translated into humans - also due to their very different volume to surface ratios.

\section{Case Study of PI3K $\gamma$ Inhibitors}

In allergy mouse models PI3K $\gamma$ targeting eliminated IgEtriggered mast cell recruitment and anaphylactic responses. A collaboration with Novartis (Thomas \& Hollingworth) provided a PI3K $\gamma$-selective inhibitor (NVS-PI3-4) to validate results obtained with genetic models targeting PI3K $\gamma$ activity. NVS-PI3-4 and the elimination of PI3K $\gamma$ both efficiently attenuated IgE/antigen-induced passive cutaneous anaphylaxis (PCA), but PI3K $\gamma$ inhibitors or a knock-in of 'kinase dead' PI3K $\delta$ showed no significant effects in PCA. ${ }^{[61]}$ While the PI3K $\gamma$ inhibitor NVS-PI3-4 had an excellent selectivity for PI3K $\gamma$ over PI3Kס, the physiological half-life was short. With Petersen (AstraZeneca), we have characterized improved compounds that show a superb PI3K $\gamma$ selectivity and provide a novel binding mode leading to conformational changes of the lipid kinase. ${ }^{[63]}$ The clinically most advanced PI3K $\gamma$ is currently IPI-549/Eganelisib, ${ }^{[62]}$ which has entered phase II clinical trials as an immuno-oncology candidate, based on the observation that $\mathrm{PI} 3 \mathrm{~K} \gamma$ inhibition could reverse tumor resistance to immune checkpoint antibodies (anti-CTLA4 and anti-PDL1). [90] Last but not least, $\mathrm{PI} 3 \mathrm{~K} \gamma$ mutations have been identified in human patients, which result in immune-pathologies. ${ }^{[91]}$ Structural and molecular dynamic studies of mutated PI3K $\gamma$ in combination with crystal structures of PI3K $\gamma$ bound to IPI-549, NVS-PI3-4, and PKI587/ Gedatolisib (a potent PI3Ki and mTOR kinase inhibitor [TORKi]) reveal novel strategies to develop PI3K $\gamma$ inhibitors with alternative binding modes. ${ }^{[92]}$

\section{From Chemical Probes to Drug Candidates}

Considering the pivotal role of PI3K in cancer and inflammation, pharma companies and academic labs have put a tremendous effort into the development of lead compounds and drugs targeting the PI3K pathway. In spite of that, only a handful of combination therapies for PI3Ki have been approved up-to-date: i) idelalisib (Zydelig/CAL-101/GS-1101; Gilead Sciences; PI3Kסi), ii) copanlisib (Aliqopa/BAY 80-6946; Bayer; PI3K $\alpha / \delta$ i), iii) duvelisib (Copiktra/IPI-145/INK1197; Verastem, now Secura Bio; PI3Kd/

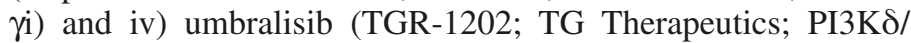
CK1عi) in specific relapsed hematological malignancies, ${ }^{\text {[9-95] }}$ and v) alpelisib (Piqray/NVP-BYL719; Novartis; PI3Koi) in advanced breast cancer bearing PI3K $\alpha$ activating mutations. ${ }^{[96]}$ High-throughput screening (HTS) campaigns of diverse compound collections together with structure-based drug design led to more than 15 chemical classes of PI3Ki, covering a broad chemical space. A broad range of PI3Ki bearing a pyrimidine, triazine, or fused pyrimidine core contains at least one morpholine moiety essential for binding into the PI3K hinge region. ${ }^{[97,98]}$ Inspired by ZSTK474, ${ }^{[99]}$ a pan PI3Ki with a triazine core, we designed and synthesized a large library of triazine derivatives which led to the identification of PQR309/bimiralisib. PQR309 broke ground after the elucidation of the mechanism of action of BKM120/buparlisib (Novartis), which has entered more than 80 clinical trials (see clinicaltrials.gov).[100]

While BKM120 and PQR309 have similar potencies as PI3Ki, BKM120 also interacts with tubulin. As a first step to deconvolute its microtubule-destabilizing agent (MDA) and PI3K activity, we separated the two biological activities of BKM120 to specifically target either PI3K or tubulin. ${ }^{[100]}$ Replacement of the BKM120 pyrimidine core with a pyridine yielded the microtubule targeting drug 147 (MTD147) with negligible PI3Ki activity (Fig. 4a), while PQR309 with a triazine core showed no detectable MDA activity.

A subsequent crystal structural investigation located BKM120 in the colchicine-binding pocket of tubulin (Fig. 4c). Despite its structural similarity to BKM120 and MTD147, PQR309's additional nitrogen in the triazine core prevents tubulin interaction. Extensive molecular dynamic simulations, combined with the synthesis of BKM120 regioisomer (Fig. 4c and d) and asymmetrically substituted derivatives, corrected the rotational orientation of BKM120 in PI3K as compared to a structure published by Burger et al. ${ }^{[101]}$ Only when BKM120 was docked into p110 $\gamma$ in a way to point the pyrimidine core $\mathrm{C}-\mathrm{H}$ towards Tyr867, the structured water network remained intact $\left(\mathrm{C}_{\mathrm{U}}-\mathrm{H}\right.$; Fig. 4c) in molecular dynamic simulations. When BKM120 was placed as proposed by Burger et al. ${ }^{[101]}\left(\mathrm{C}_{\mathrm{v}}-\mathrm{H}\right.$; Fig. $\left.4 \mathrm{~d}\right)$, the hydrogen bond interactions between inhibitor, water molecules, side chains of Asp964 and Asp836 were disrupted. ${ }^{[100]}$

PI3Ki and MDA activity were thus successfully separated by minimal chemical modifications of the core pyrimidine ring. PQR309 has been explored in phase II clinical trials for the treatment of solid tumors and lymphoma. ${ }^{[102,103]}$ After the entry of PQR309 into clinical trials, the portfolio of pre-clinical candidates with PI3K (PQR514[104]), dual PI3K/mTOR (PQR530[105]) and highly selective mTOR inhibitor activity has been enlarged, and many of these molecules were successfully assessed in tumor models and preclinical development. ${ }^{[102,104-106]}$

\section{Achieving Selectivity for mTOR}

In parallel to the development of PI3Ki and dual PI3K/mTOR inhibitors, we focused on the development of highly selective TORKi. Due to the structural similarities between the ATPbinding pockets of PI3K and mTOR, the design of compounds able to specifically inhibit mTOR kinase is challenging. Different strategies were adopted to achieve mTOR selectivity, such as (i) introduction of sterically hindered morpholines or properly sub- 

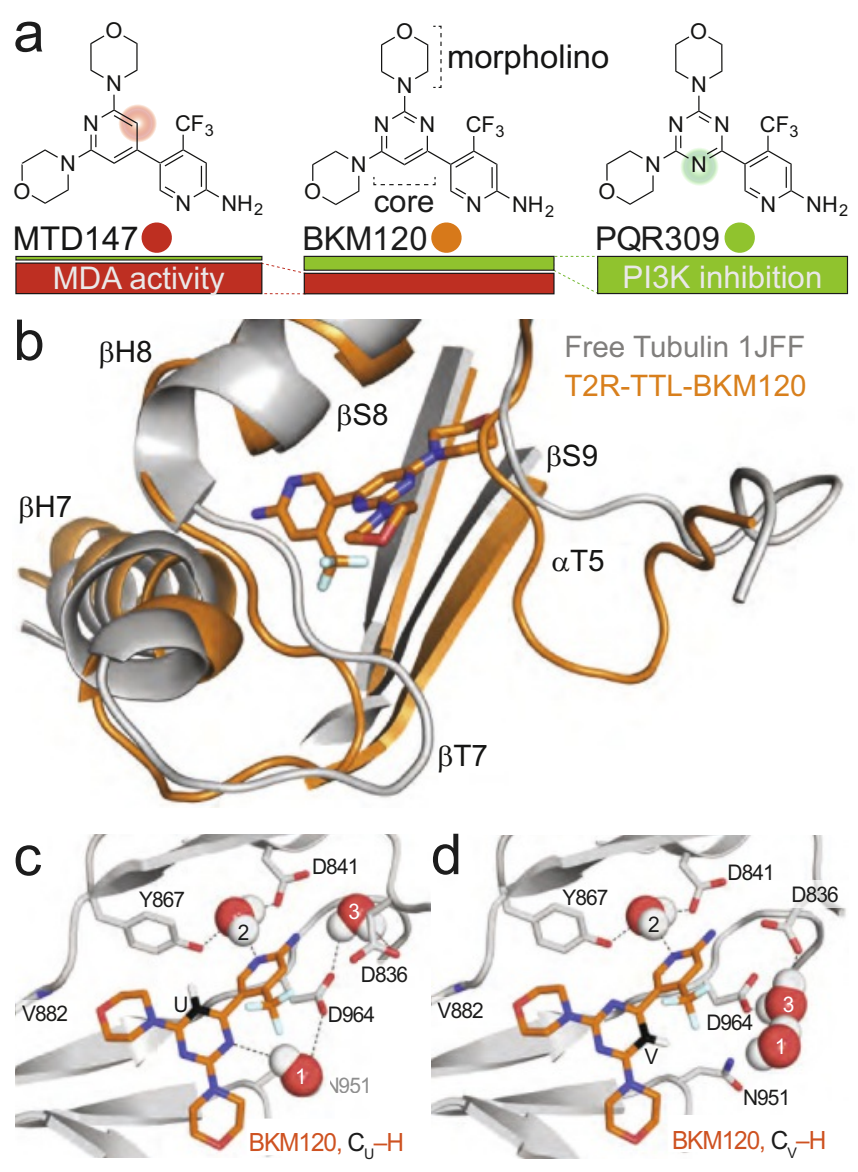

Fig. 4. a) Exchange of BKM120's pyrimidine core with pyridine yields MTD147 and with triazine yields PQR309. Rectangles below chemical formulas schematically indicate microtubule-destabilizing agent (MDA, red) and PI3K (green) inhibitor activities. b) Comparison of X-ray crystallographic structures of free tubulin (PDB ID: 1JFF) and tubulin-BKM120 complex (PDB ID: 5M7E). c,d) Two opposing orientations of BKM120 in p110 $\gamma$ were set as starting points for modelling of water movements. Positions of water dipoles after molecular dynamics calculations and energy minimization are reported.

stituted heteroaromatic rings; and (ii) a conformational restriction approach. Both the binding affinity pocket and the hinge region have been recognized as key regions in determining selectivity profiles (Fig. 5a). ${ }^{[107,108]}$ Computational studies pointed out that a leucine-phenylalanine replacement in the hinge region (Leu2354 mTOR- Phe961 PI3K $\gamma$ ) leads to a deeper pocket in mTOR compared to PI3K. ${ }^{[109]}$ For this reason, bridged morpholines are well accommodated in the hinge pocket of MTOR kinase, but cause steric clashes in PI3Ks. Starting from the dual PI3K/mTOR inhibitor PQR530, ${ }^{[105]}$ a variety of substituted morpholines were explored until a highly potent and selective TORKi (PQR620, Fig. 5b and c) was identified. PQR620 displayed a $>1000$-fold selectivity towards mTOR over PI3K $\alpha$ in binding assays, ${ }^{[110]}$ and PQR620 has been characterized as a suitable compound for rodent experiments. The excellent brain penetration allowed the use of PQR620 as proof-of-concept molecule to assess the action of ATP-competitive TORKi in mouse models of epilepsy: mice with conditional inactivation of the $T s c l$ gene primarily in glia ( $T s c 1^{\text {GFAP }}$ CKO mice) develop glial proliferation, postnatal epilepsy and show a highly increased mortality. In this Tuberous Sclerosis Complex mouse model, PQR620 (100 mg/kg, p.o.) and PQR530 (25 mg/kg, p.o.), a dual PI3K/TORKi, eliminated seizures almost completely. PQR309 (50 mg/kg, p.o.) did not reduce seizure frequency significantly, mostly due to its short half-live in mice (Fig. $5 d) .{ }^{[10]}$ PQR620 has been broadly explored in rodent tumor mod- els. ${ }^{[113-115]}$ Its limited stability in human hepatocytes, corroborated by a PK study in Cynomolgous monkey, prevented its transition to clinical trials in neurological disease and TSC patients. The ethylene bridge on the two morpholines in PQR620 has been identified as the primary metabolic liability in human liver microsomes ${ }^{[116]}$ and human hepatocytes. We therefore focused on the modification of both morpholines of PQR620 and on the development of a follow-up compound with potential improved metabolic stability in humans. An extensive investigation of the morpholine ring engaging the mTOR solvent exposed region led to the discovery of PQR626 (Fig. 5b and c), a highly potent, selective, brain penetrant TORKi. It overcame the metabolic liabilities of PQR620 and significantly reduced the loss of $T s c 1$-induced mortality at $50 \mathrm{mg} / \mathrm{kg}$ p.o. twice a day (Fig. 5d). PQR626 qualifies as a potential therapeutic candidate for the treatment of neurological disorders. [112]

Another strategy adopted for the development of highly selective TORKi was the exploitation of a conformational restriction strategy. The design of conformationally constrained analogs is often used to minimize the entropic loss associated to target binding, to enhance the potency for the target and to increase the selectivity. ${ }^{[117]}$ A rigidification strategy allowed us to disclose the tricyclic pyrimido-pyrrolo-oxazine moiety as an innovative scaffold for selectively targeting of mTOR kinase. ${ }^{[118]}$ A systematic structure-activity relationship (SAR) study identified the pyrazine derivative PQR617 as a potent TORKi showing a 212-fold selectivity over PI3K $\alpha$ (Fig. 5b and c). ${ }^{[18]}$ However, PQR617 presented a limited ability to cross the blood-brain barrier (BBB), hampering its application in the treatment of Central Nervous System (CNS) disorders such as epilepsy. Very recently, we explored different bio-isosters, and difluoro/trifluoro-substituted heteroaromatic rings on the tricyclic scaffold to modulate lipophilicity and BBB permeability. This study led to the identification of compound 11 (Fig. $5 \mathrm{~b}$ and c), bearing a $3-\mathrm{CF}_{3}$-substituted pyridine and showing MDCK-based BBB permeability. These second-generation tricyclic pyrimido-pyrrolo-oxazines pave the way for the exploitation of conformationally constrained analogs in the treatment of CNS disorders. ${ }^{[19]}$ Our lead optimization strategies provided highly selective inhibitors of mTOR kinase with tuned pharmacological profiles.

\section{Conclusions}

The converging stories of wortmannin and the still progressing assembly of the PI $3 \mathrm{~K} / \mathrm{mTOR}$ pathway is a beautiful example for the success of basic science: unrelated initial research amalgamated to accelerate progress and to provide a path to translational development. Although we have learned that the PI3K/mTOR pathway is frequently over-activated in cancer, there is still a lack of knowledge concerning the interplay of organs and systemic signals that cause severe adverse effects like hyperglycemia, insulin resistance and hyperinsulinemia due to pan-PI3Ki targeting all class I PI3Ks.

While PI3K has been explored as a therapeutic target in oncology, other applications such as chronic inflammation, cardiovascular disease and restenosis, allergy, metabolic syndrome, and more have not progressed far in clinical trials. ${ }^{[120]}$

With the help of many collaborators and fair competitors, our journey in the PI3K field - starting with the identification of wortmannin as the first $\mathrm{nM}$ PI3Ki, the deconvolution of its covalent mechanism of action, genetic mouse models in inflammation and allergy and to the present development of preclinical and clinical candidates - continues. Currently we explore covalent strategies to develop potent and selective chemical (PI3K) probes targeting kinases with the aim to alleviate adverse effects. The discovery of highly selective PI3Ki could shed light on the systemic role of the different class I PI3K isoforms in cancer and metabolism and could pave the way to the development of improved targeted therapy. 

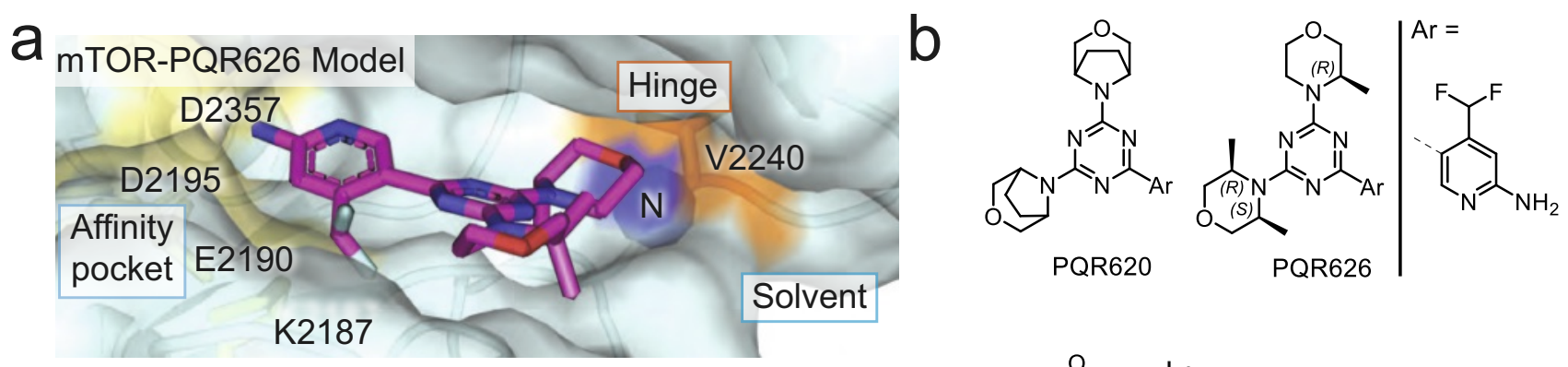

\begin{tabular}{|c|c|c|c|c|c|}
\hline Comp. $\rightarrow$ & & PQR620 & PQR626 & PQR617 & Comp. 11 \\
\hline \multirow{2}{*}{$K_{\mathrm{i}},[\mathrm{nM}]$} & mTOR & 10.8 & 3.6 & 8.0 & 33 \\
\hline & PI3Ka & 4203 & 287 & 1695 & $>20000$ \\
\hline \multicolumn{2}{|c|}{ Fold Selectivity ${ }^{a}$} & 389 & 80 & 212 & $>600$ \\
\hline
\end{tabular}

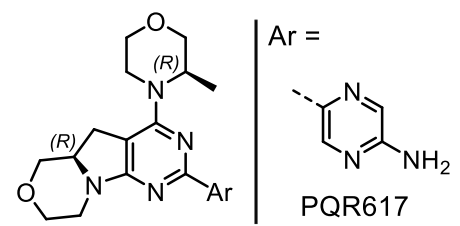<smiles>Cc1cnc(N)c(C(F)(F)F)c1</smiles>
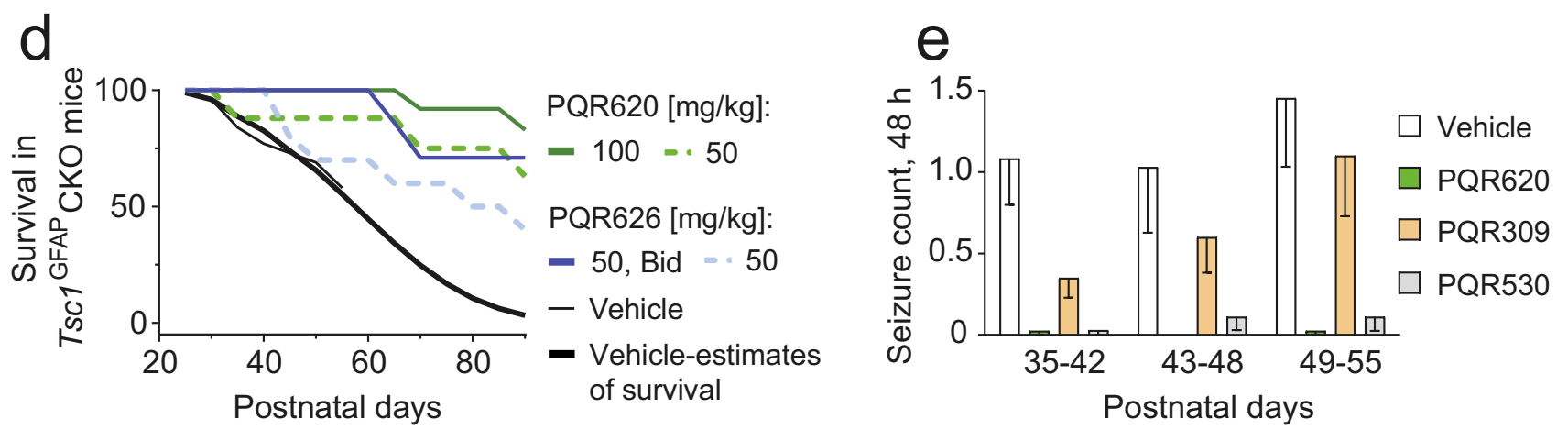

Fig. 5. a) Key regions of the mTOR catalytic site illustrated with a model of mTOR in complex with PQR626 based on PBD ID: 4JT6.[111] b) Chemical structures of highly selective TORKi developed in the Wymann Lab, bearing the triazine and tricyclic pyrimido-pyrrolo-oxazine scaffold. c) Compound potencies for mTOR and PI3K $\alpha$ and selectivity for mTOR over PI3K $\alpha$. ${ }^{a} K_{i}(P I 3 K \alpha) / K_{i}(m T O R)$. d) Effects of treatments on the survival rate of TSC1 GFAPCKO mice. ${ }^{[112]} \mathrm{e}$ ) Effects of $\mathrm{mTOR}$ and PI3K inhibition on frequency of electrographic seizures caused by neuron-specific elimination of TSC1. TsC $1^{\text {GFAP }}$ conditional knockout mice were treated from postnatal days $21-53$ with vehicle, PQR620 (100 mg/kg), PQR309 (50 mg/kg), or PQR530 (25 mg/kg). ${ }^{[113]}$

\section{Acknowledgements}

The authors gratefully acknowledge financial support by the Innosuisse grant 37213.1 IP-LS; the Novartis Foundation for medical-biological Research grant 14B095; the Swiss Commission for Technology and Innovation (CTI) PFLS-LS grant 17241.1; the Stiftung für Krebsbekämpfung grant 341 , and the Swiss National Science Foundation grants 310030_189065 and 200021_204602 to MPW.

Received: September 24, 2021

[1] M. R. Hokin, L. E. Hokin, J. Biol. Chem. 1953, 203, 967 , https://pubmed.ncbi.nlm.nih.gov/13048667/.

[2] R. H. Michell, E. G. Lapetina, Nat. New Biol. 1972, 240, 258, https://doi.org/10.1038/newbio240258a0.

[3] E. G. Lapetina, R. H. Michell, Biochem. J. 1973, 131, 433, https://doi.org/10.1042/bj1310433.

[4] H. Streb, R. F. Irvine, M. J. Berridge, I. Schulz, Nature 1983, 306, 67, https://doi.org/10.1038/306067a0.

[5] M. J. Berridge, R. F. Irvine, Nature 1984, 312, 315, https://doi.org/10.1038/312315a0.

[6] Y. Takai, A. Kishimoto, M. Inoue, Y. Nishizuka, J. Biol. Chem. 1977, 252, 7603, https://doi.org/10.1016/S0021-9258(17)41009-X.

[7] M. Inoue, A. Kishimoto, Y. Takai, Y. Nishizuka, J. Biol. Chem. 1977, 252, 7610, https://doi.org/10.1016/S0021-9258(17)41010-6.

[8] Y. Nishizuka, Science 1984, 225, 1365 , https://doi.org/10.1126/science.6147898.

[9] I. G. Macara, G. V. Marinetti, P. C. Balduzzi, Proc. Natl. Acad. Sci. USA 1984, 81, 2728, https://doi.org/10.1073/pnas.81.9.2728.

[10] Y. Sugimoto, M. Whitman, L .C. Cantley, R. L. Erikson, Proc. Natl. Acad. Sci. USA 1984, 81, 2117, https://doi.org/10.1073/pnas.81.7.2117.

[11] D. R. Kaplan, M. Whitman, B. Schaffhausen, D. C. Pallas, M. White, L. Cantley, T. M. Roberts, Cell 1987, 50, 1021, https://doi.org/10.1016/0092-8674(87)90168-1.
[12] M. Whitman, C. P. Downes, M. Keeler, T. Keller, L. Cantley, Nature 1988, 332, 644, https://doi.org/10.1038/332644a0.

[13] T. Bondeva, L. Pirola, G. Bulgarelli-Leva, I. Rubio, R. Wetzker, M. P. Wymann, Science 1998, 282, 293, https://doi.org/10.1126/science.282.5387.293.

[14] L. Pirola, M. J. Zvelebil, G. Bulgarelli-Leva, E. Van Obberghen, M. D. Waterfield, M. P. Wymann, J. Biol. Chem. 2001, 276, 21544, https://doi.org/10.1074/jbc.M011330200.

[15] A. Toker, Subcell Biochem. 2012, 58, 95, https://doi.org/10.1007/978-94-007-3012-0 4.

[16] A. E. Traynor-Kaplan, A. L. Harris, B. L. Thompson, P. Taylor, L. A. Sklar, Nature 1988, 334, 353, https://doi.org/10.1038/334353a0.

[17] A. E. Traynor-Kaplan, B. L. Thompson, A. L. Harris, P. Taylor, G. M. Omann, L. A. Sklar, J. Biol. Chem. 1989, 264, 15668,

[18] P. T. Hawkins, T. R. Jackson, L. R. Stephens, Nature 1992, 358, 157, https://doi.org/10.1038/358157a0.

[19] C. L. Carpenter, B. C. Duckworth, K. R. Auger, B. Cohen, B. S. Schaffhausen, L. C. Cantley, J. Biol. Chem. 1990, 265, 19704.

[20] I. D. Hiles, M. Otsu, S. Volinia, M. J. Fry, I. Gout, R. Dhand, G. Panayotou, F. Ruiz-Larrea, A. Thompson, N. F. Totty, Cell 1992, 70, 419, https://doi.org/10.1016/0092-8674(92)90166-a.

[21] J. Kunz, R. Henriquez, U. Schneider, M. Deuter-Reinhard, N. R. Movva, M. N. Hall, Cell 1993, 73, 585, https://doi.org/10.1016/0092-8674(93)90144-f.

[22] E. J. Brown, M. W. Albers, T. B. Shin, K. Ichikawa, C. T. Keith, W. S. Lane, S. L. Schreiber, Nature 1994, 369, 756, https://doi.org/10.1038/369756a0.

[23] J. Li, C. Yen, D. Liaw, K. Podsypanina, S. Bose, S.I. Wang, J. Puc, C. Miliaresis, L. Rodgers, R. McCombie, S. H. Bigner, B. C. Giovanella, M. Ittmann, B. Tycko, H. Hibshoosh, M. H. Wigler, R. Parsons, Science 1997, 275, 1943, https://doi.org/10.1126/science.275.5308.1943.

[24] T. Maehama, J. E. Dixon, J. Biol. Chem. 1998, 273, 13375 , https://doi.org/10.1074/jbc.273.22.13375.

[25] V. Stambolic, A. Suzuki, J. L. de la Pompa, G. M. Brothers, C. Mirtsos, T. Sasaki, J. Ruland, J. M. Penninger, D. P. Siderovski, T. W. Mak, Cell 1998, 95, 29, https://doi.org/10.1016/s0092-8674(00)81780-8.

[26] M. P. Myers, I. Pass, I. H. Batty, J. Van der Kaay, J. P. Stolarov, B. A. Hemmings, M. H. Wigler, C. P. Downes, N. K. Tonks, Proc. Natl. Acad. Sci. USA 1998, 95, 13513, https://doi.org/10.1073/pnas.95.23.13513. 
[27] Y. Samuels, Z. Wang, A. Bardelli, N. Silliman, J. Ptak, S. Szabo, H. Yan, A. Gazdar, S. M. Powell, G. J. Riggins, J. K. Willson, S. Markowitz, K. W. Kinzler, B. Vogelstein, V. E. Velculescu, Science 2004, 304, 554 , https://doi.org/10.1126/science.1096502.

[28] Y. Samuels, L. A. Diaz, O. Schmidt-Kittler, J. M. Cummins, L. Delong, I. Cheong, C. Rago, D. L. Huso, C. Lengauer, K. W. Kinzler, B. Vogelstein, V. E. Velculescu, Cancer Cell 2005, 7, 561, https://doi.org/10.1016/j.ccr.2005.05.014.

[29] S. J. Isakoff, J. A. Engelman, H. Y. Irie, J. Luo, S. M. Brachmann, R. V. Pearline, L. C. Cantley, J. S. Brugge, Cancer Res. 2005, 65, 10992, https://doi.org/10.1158/0008-5472.CAN-05-2612.

[30] S. Kang, A. G. Bader, P. K. Vogt, Proc. Natl. Acad. Sci. USA 2005, 102, 802, https://doi.org/10.1073/pnas.0408864102.

[31] L. Bi, I. Okabe, D.J. Bernard, A. Wynshaw-Boris, R.L. Nussbaum, J. Biol. Chem. 1999, 274, 10963, https://doi.org/10.1074/jbc.274.16.10963.

[32] L. Bi, I. Okabe, D. J. Bernard, R. L. Nussbaum, Mamm. Genome 2002, 13 , 169, https://doi.org/10.1007/BF02684023.

[33] P. W. Brian, P. J. Curtis, H. G. Hemming, G. L. F. Norris, Trans. Br. Mycol. Soc. 1957, 40, 365, https://doi.org/10.1016/s0007-1536(57)80033-3.

[34] R. W. Bonser, N. T. Thompson, R. W. Randall, J. E. Tateson, G. D. Spacey, H. F. Hodson, L. G. Garland, Br. J. Pharmacol. 1991, 103, 1237, https://doi.org/10.1111/j.1476-5381.1991.tb12330.x.

[35] S. Nakanishi, S. Kakita, I. Takahashi, K. Kawahara, E. Tsukuda, T. Sano, K. Yamada, M. Yoshida, H. Kase, Y. Matsuda, J. Biol. Chem. 1992, 267, 2157.

[36] M. P. Wymann, G. Bulgarelli-Leva, M. J. Zvelebil, L. Pirola, B. Vanhaesebroeck, M. D. Waterfield, G. Panayotou, Mol. Cell Biol. 1996, 16, 1722, https://doi.org/10.1128/MCB.16.4.1722.

[37] W. Haefliger, Z. Kis, D. Hauser, Helv. Chim. Acta 1975, 58, 1620,

[38] H. Yano, S. Nakanishi, K. Kimura, N. Hanai, Y. Saitoh, Y. Fukui, Y Nonomura, Y. Matsuda, J. Biol. Chem. 1993, 268, 25846,

[39] T. J. Petcher, H.-P. Weber, Z. Kis, J. Chem. Soc. Chem. Comm. 1972, 1061 , https://doi.org/10.1039/c39720001061.

[40] A. Closse, W. Haefliger, D. Hauser, H. U. Gubler, B. Dewald, M. Baggiolini, J. Med. Chem. 1981, 24, 1465, https://doi.org/10.1021/jm00144a019.

[41] R. Gunther, P. N. Kishore, H. K. Abbas, C. J. Mirocha, Immunopharmacol. Immunotoxicol.1989,11,559, https://doi.org/10.3109/08923978909005385.

[42] M. Baggiolini, B. Dewald, J. Schnyder, W. Ruch, P. H Cooper, T. G. Payne, Exp. Cell Res. 1987, 169, 408, https://doi.org/10.1016/0014-4827(87)90201-1.

[43] M. P. Wymann, V. von Tscharner, D. A. Deranleau, M. Baggiolini, Anal. Biochem. 1987, 165, 371, https://doi.org/10.1016/0003-2697(87)90284-3.

[44] M. P. Wymann, P. Kernen, D. A. Deranleau, B. Dewald, V. von Tscharner, M. Baggiolini, Biochem. Biophys. Res. Commun. 1987, 147, 361, https://doi.org/10.1016/s0006-291x(87)80130-4.

[45] M. P. Wymann, P. Kernen, D. A. Deranleau, M. Baggiolini, J. Biol. Chem. 1989, 264, 15829, https://doi.org/10.1016/S0021-9258(18)71552-4.

[46] M. P. Wymann, P. Kernen, T. Bengtsson, T. Andersson, M. Baggiolini, D. A. Deranleau, J. Biol. Chem. 1990, 265, 619, https://doi.org/10.1016/S0021-9258(19)40094-X.

[47] A. Arcaro, M. P. Wymann, Biochem. J. 1993, 296, 297, https://doi.org/10.1042/bj2960297.

[48] M. Wymann, A. Arcaro, Biochem. J. 1994, 298 Pt 3, 517, https://doi.org/10.1042/bj2980517.

[49] M. Thelen, M. P. Wymann, H. Langen, Proc. Natl. Acad. Sci. USA 1994, 91, 4960, https://doi.org/10.1073/pnas.91.11.4960.

[50] S. Stoyanova, G. Bulgarelli-Leva, C. Kirsch, T. Hanck, R. Klinger, R. Wetzker, M. P. Wymann, Biochem. J. 1997, 324, 489, https://doi.org/10.1042/bj3240489.

[51] E. H. Walker, M. E. Pacold, O. Perisic, L. Stephens, P. T. Hawkins, M. P. Wymann, R. L. Williams, Mol. Cell 2000, 6, 909, https://doi.org/10.1016/s1097-2765(05)00089-4

[52] T. Zhu, J. Gu, K. Yu, J. Lucas, P. Cai, R. Tsao, Y. Gong, F. Li, I. Chaudhary, P. Desai, M. Ruppen, M. Fawzi, J. Gibbons, S. Ayral-Kaloustian, J. Skotnicki, T. Mansour, A. Zask, J. Med. Chem. 2006, 49, 1373 , https://doi.org/10.1021/jm050901o.

[53] N. T. Ihle, R. Williams, S. Chow, W. Chew, M. I. Berggren, G. PaineMurrieta, D. J. Minion, R. J. Halter, P. Wipf, R. Abraham, L. Kirkpatrick, G. Powis, Mol. Cancer Ther. 2004, 3, 763.

[54] C. J. Vlahos, W. F. Matter, K. Y. Hui, R. F. Brown, J. Biol. Chem. 1994, 269, 5241, https://doi.org/10.1016/S0021-9258(17)37680-9.

[55] S. P. Staal, Proc. Natl. Acad. Sci. USA 1987, 84, 5034, https://doi.org/10.1073/pnas.84.14.5034

[56] P. F. Jones, T. Jakubowicz, F. J. Pitossi, F. Maurer, B. A. Hemmings, Proc. Natl. Acad. Sci. USA 1991, 88, 4171, https://doi.org/10.1073/pnas.88.10.4171.

[57] B. M. Burgering, P. J. Coffer, Nature 1995, 376, 599, https://doi.org/10.1038/376599a0

[58] D. R. Alessi, S. R. James, C. P. Downes, A. B. Holmes, P. R. Gaffney, C. B. Reese, P. Cohen, Curr. Biol. 1997, 7, 261, https://doi.org/10.1016/s0960-9822(06)00122-9.

[59] M. Camps, T. Rückle, H. Ji, V. Ardissone, F. Rintelen, J. Shaw, C. Ferrandi,
C. Chabert, C. Gillieron, B. Françon, T. Martin, D. Gretener, D. Perrin, D. Leroy, P. A. Vitte, E. Hirsch, M. P. Wymann, R. Cirillo, M. K. Schwarz, C. Rommel, Nat. Med. 2005, 11, 936, https://doi.org/10.1038/nm1284.

[60] I. Bruce, M. Akhlaq, G. C. Bloomfield, E. Budd, B. Cox, B. Cuenoud, P. Finan, P. Gedeck, J. Hatto, J. F. Hayler, D. Head, T. Keller, L. Kirman, C. Leblanc, D. Le Grand, C. McCarthy, D. O'Connor, C. Owen, M. S. Oza, G. Pilgrim, N. E. Press, L. Sviridenko, L. Whitehead, Bioorg. Med. Chem. Lett. 2012, 22, 5445, https://doi.org/10.1016/j.bmcl.2012.07.042.

[61] E. Collmann, T. Bohnacker, R. Marone, J. Dawson, M. Rehberg, R. Stringer, F. Krombach, C. Burkhart, E. Hirsch, G. J. Hollingworth, M Thomas, M. P. Wymann, J. Allergy Clin. Immunol. 2013, 132, 959, https://doi.org/10.1016/j.jaci.2013.03.008

[62] C. A. Evans, T. Liu, A. Lescarbeau, S. J. Nair, L. Grenier, J. A. Pradeilles, Q. Glenadel, T. Tibbitts, A. M. Rowley, J. P. DiNitto, E. E. Brophy, E. L. O'Hearn, J. A. Ali, D. G. Winkler, S. I. Goldstein, P. O'Hearn, C. M. Martin, J. G. Hoyt, J. R. Soglia, C. Cheung, M. M. Pink, J. L. Proctor, V. J. Palombella, M. R. Tremblay, A. C. Castro, ACS Med. Chem. Lett. 2016, 7 , 862, https://doi.org/10.1021/acsmedchemlett.6b00238.

63] G. Gangadhara, G. Dahl, T. Bohnacker, R. Rae, J. Gunnarsson, S. Blaho, L. Öster, H. Lindmark, K. Karabelas, N. Pemberton, C. Tyrchan, M. Mogemark, M. P. Wymann, R. L. Williams, M. W. D. Perry, T. Papavoine, J. Petersen, Nat. Chem. Biol. 2019, 15, 348, https://doi.org/10.1038/s41589-018-0215-0.

[64] J. Chung, T. C. Grammer, K. P. Lemon, A. Kazlauskas, J. Blenis, Nature 1994, 370, 71, https://doi.org/10.1038/370071a0.

[65] G. J. Brunn, J. Williams, C. Sabers, G. Wiederrecht, J. C. Lawrence, R. T. Abraham, EMBO J. 1996, 15, 5256.

[66] D. D. Sarbassov, D. A. Guertin, S. M. Ali, D. M. Sabatini, Science 2005, 307, 1098, https://doi.org/10.1126/science.1106148.

[67] T. Gao, F. Furnari, A. C. Newton, Mol. Cell 2005, 18, 13, https://doi.org/10.1016/j.molcel.2005.03.008.

[68] Q. Yang, K. Inoki, T. Ikenoue, K. L. Guan, Genes Dev. 2006, 20, 2820, https://doi.org/10.1101/gad.1461206.

[69] E. Jacinto, V. Facchinetti, D. Liu, N. Soto, S. Wei, S. Y. Jung, Q. Huang, J. Qin, B. Su, Cell 2006, 127, 125, https://doi.org/10.1016/j.cell.2006.08.033.

[70] M. P. Wymann, R. Schneiter, Nat. Rev. Mol. Cell Biol. 2008, 9, 162 https://doi.org/10.1038/nrm2335.

[71] G. Y. Liu, D. M. Sabatini, Nat. Rev. Mol. Cell Biol. 2020, 21, 183 , https://doi.org/10.1038/s41580-019-0199-y.

[72] Z. Li, H. Jiang, W. Xie, Z. Zhang, A. V. Smrcka, D. Wu, Science 2000, 287 , 1046, https://doi.org/10.1126/science.287.5455.1046.

[73] T. Sasaki, J. Irie-Sasaki, R. G. Jones, A. J. Oliveira-dos-Santos, W. L. Stanford, B. Bolon, A. Wakeham, A. Itie, D. Bouchard, I. Kozieradzki, N. Joza, T. W. Mak, P. S. Ohashi, A. Suzuki, J. M. Penninger, Science 2000, 287, 1040, https://doi.org/10.1126/science.287.5455.1040.

[74] E. Hirsch, M. P. Wymann, E. Patrucco, E. Tolosano, G. BulgarelliLeva, S. Marengo, M. Rocchi, F. Altruda, Gene 2000, 256, 69, https://doi.org/10.1016/s0378-1119(00)00328-0.

[75] E. Hirsch, V. L. Katanaev, C. Garlanda, O. Azzolino, L. Pirola, L. Silengo, S. Sozzani, A. Mantovani, F. Altruda, M. P. Wymann, Science 2000, 287, 1049, https://doi.org/10.1126/science.287.5455.1049.

[76] M. P. Wymann, S. Sozzani, F. Altruda, A. Mantovani, E. Hirsch, Immunol. Today 2000, 21, 260, https://doi.org/10.1016/s0167-5699(00)01649-2.

177] A. Del Prete, W. Vermi, E. Dander, K. Otero, L. Barberis, W. Luini, S. Bernasconi, M. Sironi, A. Santoro, C. Garlanda, F. Facchetti, M. P. Wymann, A. Vecchi, E. Hirsch, A. Mantovani, S. Sozzani, EMBO J. 2004, 23, 3505, https://doi.org/10.1038/sj.emboj.7600361.

[78] V. L. Katanaev, M. P. Wymann, J. Cell Sci. 1998, 111, 1583, https://doi.org/10.1242/jcs.111.11.1583.

[79] G. E. Jones, E. Prigmore, R. Calvez, C. Hogan, G. A. Dunn, E Hirsch, M. P. Wymann, A. J. Ridley, Exp. Cell Res. 2003, 290, 120, https://doi.org/10.1016/s0014-4827(03)00318-5.

[80] G. J. Ferguson, L. Milne, S. Kulkarni, T. Sasaki, S. Walker, S. Andrews, T. Crabbe, P. Finan, G. Jones, S. Jackson, M. Camps, C. Rommel, M. Wymann, E. Hirsch, P. Hawkins, L. Stephens, Nat. Cell Biol. 2007, 9, 86, https://doi.org/10.1038/ncb1517.

[81] E. Lupia, A. Goffi, P. De Giuli, O. Azzolino, O. Bosco, E. Patrucco, M. C. Vivaldo, M. Ricca, M. P. Wymann, E. Hirsch, G. Montrucchio, G. Emanuelli, Am. J. Pathol. 2004, 165, 2003, https://doi.org/10.1016/s0002-9440(10)63251-8.

[82] A. Fougerat, S. Gayral, P. Gourdy, A. Schambourg, T. Rückle, M. K Schwarz, C. Rommel, E. Hirsch, J. F. Arnal, J. P. Salles, B. Perret, M. Breton-Douillon, M. P. Wymann, M. Laffargue, Circulation 2008, 117, 1310, https://doi.org/10.1161/CIRCULATIONAHA.107.720466.

[83] A. Fougerat, N. F. Smirnova, S. Gayral, N. Malet, E. Hirsch, M. P. Wymann, B. Perret, L. O. Martinez, M. Douillon, M. Laffargue, Br. J. Pharmacol. 2012, 166, 1643, https://doi.org/10.1111/j.1476-5381.2012.01866.x.

[84] T. M. Zotes, C. F. Arias, J. J. Fuster, R. Spada, S. Pérez-Yagüe, E. Hirsch, M. Wymann, A.C. Carrera, V. Andrés, D. F. Barber, PLoS One 2013, 8, e72674, https://doi.org/10.1371/journal.pone.0072674.

[85] J. J. Anzinger, J. Chang, Q. Xu, M. K. Barthwal, T. Bohnacker, M. P. Wymann, H. S. Kruth, J. Lipid Res. 2012, 53, 34, 
https://doi.org/10.1194/jlr.M018887.

[86] M. K. Barthwal, J. J. Anzinger, Q. Xu, T. Bohnacker, M. P. Wymann, H. S. Kruth, PLoS One 2013, 8, e58054, https://doi.org/10.1371/journal.pone.0058054.

[87] E. Patrucco, A. Notte, L. Barberis, G. Selvetella, A. Maffei, M. Brancaccio, S. Marengo, G. Russo, O. Azzolino, S. D. Rybalkin, L. Silengo, F. Altruda, R. Wetzker, M. P. Wymann, G. Lembo, E. Hirsch, Cell 2004, 118, 375, https://doi.org/10.1016/j.cell.2004.07.017.

[88] B. Becattini, R. Marone, F. Zani, D. Arsenijevic, J. Seydoux, J. P. Montani, A. G. Dulloo, B. Thorens, F. Preitner, M. P. Wymann, G. Solinas, Proc. Natl. Acad. Sci. USA 2011, 108, E854, https://doi.org/10.1073/pnas.1106698108.

[89] L. Breasson, B. Becattini, C. Sardi, A. Molinaro, F. Zani, R. Marone, F. Botindari, M. Bousquenaud, C. Ruegg, M. P. Wymann, G. Solinas, Sci. Signal 2017, 10, eaaf2969, https://doi.org/10.1126/scisignal.aaf2969.

[90] O. De Henau, M. Rausch, D. Winkler, L. F. Campesato, C. Liu, D. H. Cymerman, S. Budhu, A. Ghosh, M. Pink, J. Tchaicha, M. Douglas, T. Tibbitts, S. Sharma, J. Proctor, N. Kosmider, K. White, H. Stern, J. Soglia, J. Adams, V. J. Palombella, K. McGovern, J. L. Kutok, J. D. Wolchok, T. Merghoub, Nature 2016, 539, 443, https://doi.org/10.1038/nature20554.

[91] A. J. Takeda, T. J. Maher, Y. Zhang, S. M. Lanahan, M. L. Bucklin, S. R. Compton, P. M. Tyler, W. A. Comrie, M. Matsuda, K. N. Olivier, S. Pittaluga, J. J. McElwee, D. A. Long Priel, D. B. Kuhns, R .L. Williams, P. J. Mustillo, M. P. Wymann, V. Koneti Rao, C. L. Lucas, Nat. Commun. 2019, 10, 4364, https://doi.org/10.1038/s41467-019-12311-5.

[92] M. K. Rathinaswamy, Z. Gaieb, K. D. Fleming, C. Borsari, N. J. Harris, B. E. Moeller, M. P. Wymann, R. E. Amaro, J. E. Burke, Elife 2021, 10, e64691, https://doi.org/10.7554/eLife.64691.

[93] F. Janku, T. A. Yap, F. Meric-Bernstam, Nat. Rev. Clin. Oncol. 2018, 15 , 273, https://doi.org/10.1038/nrclinonc.2018.28

[94] I. W. Flinn, S. O'Brien, B. Kahl, M. Patel, Y. Oki, F. F. Foss, P. Porcu, J. Jones, J. A. Burger, N. Jain, V. M. Kelly, K. Allen, M. Douglas, J. Sweeney, P. Kelly, S. Horwitz, Blood 2018, 131, 877, https://doi.org/10.1182/blood-2017-05-786566.

[95] H. A. Burris, I. W. Flinn, M. R. Patel, T. S. Fenske, C. Deng, D. M. Brander, M. Gutierrez, J. H. Essell, J. G. Kuhn, H. P. Miskin, P. Sportelli, M. S. Weiss, S. Vakkalanka, M. R. Savona, O. A. O'Connor, Lancet Oncol. 2018, 19, 486, https://doi.org/10.1016/S1470-2045(18)30082-2.

[96] A. Markham, Drugs 2019, 79, 1249, https://doi.org/10.1007/s40265-019-01161-6.

[97] A. E. Garces, M. J. Stocks, J. Med. Chem. 2019, 62, 4815, https://doi.org/10.1021/acs.jmedchem.8b01492.

[98] B. Vanhaesebroeck, M. W. D. Perry, J. R. Brown, F. André, K. Okkenhaug, Nat. Rev. Drug Discov. 2021, 20, 741, https://doi.org/10.1038/s41573-021-00209-1.

[99] S. Yaguchi, Y. Fukui, I. Koshimizu, H. Yoshimi, T. Matsuno, H. Gouda, S. Hirono, K. Yamazaki, T. Yamori, J. Natl. Cancer Inst. 2006, 98, 545, https://doi.org/10.1093/jnci/dji133.

[100] T. Bohnacker, A. E. Prota, F. Beaufils, J. E. Burke, A. Melone, A. J. Inglis, D. Rageot, A. M. Sele, V. Cmiljanovic, N. Cmiljanovic, K. Bargsten, A. Aher, A. Akhmanova, J. F. Díaz, D. Fabbro, M. Zvelebil, R. L. Williams, M. O. Steinmetz, M. P. Wymann, Nat. Commun. 2017, 8, 14683, https://doi.org/10.1038/ncomms14683

[101] M. T. Burger, S. Pecchi, A. Wagman, Z. J. Ni, M. Knapp, T. Hendrickson, G. Atallah, K. Pfister, Y. Zhang, S. Bartulis, K. Frazier, S. Ng, A. Smith, J. Verhagen, J. Haznedar, K. Huh, E. Iwanowicz, X. Xin, D. Menezes, H. Merritt, I. Lee, M. Wiesmann, S. Kaufman, K. Crawford, M. Chin, D. Bussiere, K. Shoemaker, I. Zaror, S. M. Maira, C. F. Voliva, ACS Med. Chem. Lett. 2011, 2, 774, https://doi.org/10.1021/ml200156t.

[102] C. Tarantelli, E. Gaudio, A. J. Arribas, I. Kwee, P. Hillmann, A. Rinaldi, L. Cascione, F. Spriano, E. Bernasconi, F. Guidetti, L. Carrassa, R. B. Pittau, F. Beaufils, R. Ritschard, D. Rageot, A. Sele, B. Dossena, F. M. Rossi, A. Zucchetto, M. Taborelli, V. Gattei, D. Rossi, A. Stathis, G. Stussi, M. Broggini, M. P. Wymann, A. Wicki, E. Zucca, V. Cmiljanovic, D. Fabbro, F. Bertoni, Clin. Cancer Res. 2018, 24, 120, https://doi.org/10.1158/1078-0432.CCR-17-1041.

[103] A. Wicki, N. Brown, A. Xyrafas, V. Bize, H. Hawle, S. Berardi, N. Cmiljanović, V. Cmiljanović, M. Stumm, S. Dimitrijevi?, R. Herrmann, V. Prêtre, R. Ritschard, A. Tzankov, V. Hess, A. Childs, C. Hierro, J. Rodon, D. Hess, M. Joerger, R. von Moos, C. Sessa, R. Kristeleit, Eur. J. Cancer 2018, 96, 6, https://doi.org/10.1016/j.ejca.2018.03.012.
[104] C. Borsari, D. Rageot, F. Beaufils, T. Bohnacker, E. Keles, I. Buslov, A. Melone, A. M. Sele, P. Hebeisen, D. Fabbro, P. Hillmann, M. P. Wymann, ACS Med. Chem. Lett. 2019, 10, 1473, https://doi.org/10.1021/acsmedchemlett.9b00333.

[105] D. Rageot, T. Bohnacker, E. Keles, J. A. McPhail, R. M. Hoffmann, A. Melone, C. Borsari, R. Sriramaratnam, A. M. Sele, F. Beaufils, P. Hebeisen, D. Fabbro, P. Hillmann, J. E. Burke, M. P. Wymann, J. Med. Chem. 2019 , 62, 6241, https://doi.org/10.1021/acs.jmedchem.9b00525.

[106] C. Tarantelli, E. Gaudio, P. Hillmann, F. Spriano, G. Sartori, L. Aresu, L. Cascione, D. Rageot, I. Kwee, F. Beaufils, E. Zucca, A. Stathis, M. P. Wymann, V. Cmiljanovic, D. Fabbro, F. Bertoni, Cancers (Basel) 2019, 11, E775, https://doi.org/10.3390/cancers11060775.

[107] M. Moll, P. W. Finn, L. E. Kavraki, BMC Genomics 2016, 17 Suppl 4, 431, https://doi.org/10.1186/s12864-016-2790-3.

[108] C. Borsari, M. De Pascale, M. P. Wymann, ChemMedChem 2021, 16, 2744, https://doi.org/10.1002/cmdc.202100332.

[109] A. Zask, J. Kaplan, J. C. Verheijen, D. J. Richard, K. Curran, N. Brooijmans, E. M. Bennett, L. Toral-Barza, I. Hollander, S. Ayral-Kaloustian, K. Yu, J. Med. Chem. 2009, 52, 7942, https://doi.org/10.1021/jm901415x.

[110] D. Rageot, T. Bohnacker, A. Melone, J. B. Langlois, C. Borsari, P. Hillmann, A. M. Sele, F. Beaufils, M. Zvelebil, P. Hebeisen, W. Löscher, J. Burke, D. Fabbro, M. P. Wymann, J. Med. Chem. 2018, 61, 10084, https://doi.org/10.1021/acs.jmedchem.8b01262.

[111] H. Yang, D. G. Rudge, J. D. Koos, B. Vaidialingam, H. J. Yang, N. P. Pavletich, Nature 2013, 497, 217, https://doi.org/10.1038/nature12122.

[112] C. Borsari, E. Keles, D. Rageot, A. Treyer, T. Bohnacker, L. Bissegger, M. De Pascale, A. Melone, R. Sriramaratnam, F. Beaufils, M. Hamburger, P. Hebeisen, W. Löscher, D. Fabbro, P. Hillmann, M. P. Wymann, J. Med. Chem. 2020, 63, 13595, https://doi.org/10.1021/acs.jmedchem.0c00620.

[113] W. Theilmann, B. Gericke, A. Schidlitzki, S. M. Muneeb Anjum, S. Borsdorf, T. Harries, S. L. Roberds, D. J. Aguiar, D. Brunner, S. C. Leiser, D. Song, D. Fabbro, P. Hillmann, M. P. Wymann, W. Löscher, Neuropharmacology 2020, 180, 108297, https://doi.org/10.1016/j.neuropharm.2020.108297.

[114] C. Brandt, P. Hillmann, A. Noack, K. Römermann, L. A. Öhler, D. Rageot, F. Beaufils, A. Melone, A. M. Sele, M. P. Wymann, D. Fabbro, W. Löscher, Neuropharmacology 2018, 140, 107, https://doi.org/10.1016/j.neuropharm.2018.08.002.

[115] E. Singer, C. Walter, D. Fabbro, D. Rageot, F. Beaufils, M. P. Wymann, N. Rischert, O. Riess, P. Hillmann, H. P. Nguyen, Neuropharmacology 2020 162, 107812, https://doi.org/10.1016/j.neuropharm.2019.107812.

[116] A. M. Venkatesan, Z. Chen, O. dos Santos, C. Dehnhardt, E. D. Santos, S Ayral-Kaloustian, R. Mallon, I. Hollander, L. Feldberg, J. Lucas, K. Yu, I. Chaudhary, T. S. Mansour, Bioorg. Med. Chem. Lett. 2010, 20, 5869, https://doi.org/10.1016/j.bmcl.2010.07.104.

[117] Z. Fang, Y. Song, P. Zhan, Q. Zhang, X. Liu, Future Med. Chem. 2014, 6, 885, https://doi.org/10.4155/fmc.14.50.

[118] C. Borsari, D. Rageot, A. Dall'Asen, T. Bohnacker, A. Melone, A. M. Sele, E. Jackson, J. B. Langlois, F. Beaufils, P. Hebeisen, D. Fabbro, P. Hillmann, M. P. Wymann, J. Med. Chem. 2019, 62, 8609, https://doi.org/10.1021/acs.jmedchem.9b00972.

[119] C. Borsari, E. Keles, A. Treyer, M. De Pascale, P. Hebeisen, M. Hamburger, M. P. Wymann, RSC Med. Chem. 2021, 12, 579, https://doi.org/10.1039/d0md00408a.

[120] S. M. Lanahan, M. P. Wymann, C. L. Lucas, Nat. Rev. Immunol. 2022, accepted article.

\section{License and Terms}

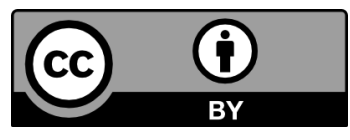

This is an Open Access article under the terms of the Creative Commons Attribution License CC BY 4.0. The material may not be used for commercial purposes.

The license is subject to the CHIMIA terms and conditions: (http:// chimia.ch/component/sppagebuilder/?view=page \&id=12).

The definitive version of this article is the electronic one that can be found at https://doi.org/10.2533/chimia.2021.1037 